\title{
Near Surface Characterization of Ebem Community, Ohafia Abia State, Using Seismic Refraction Tomography
}

\author{
Nwankwo C.N. ${ }^{1}$, Ogagarue D.O. ${ }^{2, *}$ \\ ${ }^{1}$ Department of Physics, University of Port Harcourt, Nigeria \\ ${ }^{2}$ Department of Earth Sciences, Federal University of Petroleum Resources, Effurun, Nigeria \\ *Corresponding author: ogagarue.odeyovwi@fupre.edu.ng
}

Received January 03, 2019; Revised February 05, 2019; Accepted February 13, 2019

\begin{abstract}
Seismic refraction tomography was carried out in Ebem community, Ohafia, eastern Nigeria, which recently experienced erosional landslide. The aim was to determine the near surface characteristics in the area, offer possible geologic explanation to the frequent landslides which occur in the area and provide information on potential slide zones to mitigate future disasters. A total of three seismic refraction profiles were carried out using a 12-channel ABEM Terrace MK III digital seismograph with inter-channel spacing of $10 \mathrm{~m}$. Shots were generated by means of a $6 \mathrm{~kg}$ sledge hammer and metal plates at $23.5 \mathrm{~m}$ before the first and after the last geophone group respectively, and at every geophone station, giving a total length of $157 \mathrm{~m}$ for each profile. Velocity structure from the study shows that the area is made up of three different layers on account of velocity distribution, which includes a top layer of unconsolidated, low velocity dry sands assumed to be weathering layer with velocity ranging from about $412 \mathrm{~m} / \mathrm{s}$ to $1,300 \mathrm{~m} / \mathrm{s}$. This layer varies in thickness from about $9 \mathrm{~m}$ at the flanks to about $35 \mathrm{~m}$ at the center, creating a thick zone of low velocity at the center. This is underlain by a very thin, apparently more compacted sub-weathering layer containing a mixture of sands and clay in which velocity and thickness vary from about 1,300 $\mathrm{m} / \mathrm{s}$ to $3,000 \mathrm{~m} / \mathrm{s}$, and 2,31 m to $3.01 \mathrm{~m}$ respectively. Compressional velocity in the area varies from about $412 \mathrm{~m} / \mathrm{s}$ to about $4.090 \mathrm{~m} / \mathrm{s}$, and velocities in the bedrock generally exceed 3,000 m/s; the velocity generally increasing with depth from the surface. The results suggest that the frequent landslides in the area are likely the result of the thick, unconsolidated and permeable dry sands underneath the surface which presumably acts as a sinkhole for surface water run-offs orchestrated by the frequent rainfall which is common in the area. Areas with the highest thickness of weathering are the most vulnerable to sliding in the area.
\end{abstract}

Keywords: seismic refraction tomography, near surface characteristics, weathering layer, Ebem, velocity structure, landslide, refraction profile

Cite This Article: Nwankwo C.N., and Ogagarue D.O., "Near Surface Characterization of Ebem Community, Ohafia Abia State, Using Seismic Refraction Tomography.” Journal of Geosciences and Geomatics, vol. 7, no. 2 (2019): 73-79. doi: 10.12691/jgg-7-2-3.

\section{Introduction}

Many communities in Ohafia, Abia State have in recent times been ravaged with slope failures and landslides (Figure 1) resulting to loss of farm lands, roads, economic trees and other infrastructures. Landslide refers to the downslope movement of a mass of rock, soil and organic materials under the influence of gravity and the landform resulting from such movements. The cause of the Ebem landslide disaster has been attributed mainly to heavy rainfall that creates gullies by washing away top soils and rocks, and human activities such as excavation of the top soils and laterites from the developing areas within the community. In the several attempts by local authorities to seek for ways to mitigate the risk and reduce the disaster associated with the landslides, less emphasis has so far been placed on the type and strength of subsurface geologic materials in the area which could be a pathway to erosions as well as affect foundations of large civil engineering structures in the area. An understanding of geology in terms of the velocity structure of the landslide mass, depth to failure surface and spatial variability of the landmass is important in the study of landslides.

Seismic refraction tomography is a useful tool in the investigation of landslides. Seismic refraction tomography had been used in the past for groundwater investigation and mapping of groundwater aquifers within basement complex zones $[1,2,3]$. Seismic tomography is an imaging technique [4]. Through this technique, the deep structure of the earth's subsurface can be probed and its geologic characteristics imaged. The procedure is an inverse problem whereby inferences are made concerning the properties of the subsurface rock materials through which seismic waves have passed by analyzing seismic data at 
the surface [5]. Among the different methods used in seismic tomography, refraction tomographic inversion of first arrival travel times is the most reliable in making a shallow low-resolution velocity structure of the earth's subsurface. Seismic refraction tomography utilizes the same shooting procedure as the conventional refraction methods, except that multiple shots and recorders [6] simultaneously apply in refraction tomography. In practice, many shots are taken before the first receiver group, at each receiver location and beyond the far receiver group. Through gridded inversion of the first arrival travel times of refracted seismic energy recorded at the stations, the method is able to interpret velocity changes in the subsurface as gradient with respect to depth of the subsurface along the profile but not necessarily in relation to the medium or refractor with high velocity contrast $[7,8,9]$. The method is therefore suitable for delineating both vertical and lateral variations in near surface characteristics. The velocity structure of a landslide can be quite complex and by design, can be modeled quite accurately and with high resolution using refraction tomography.

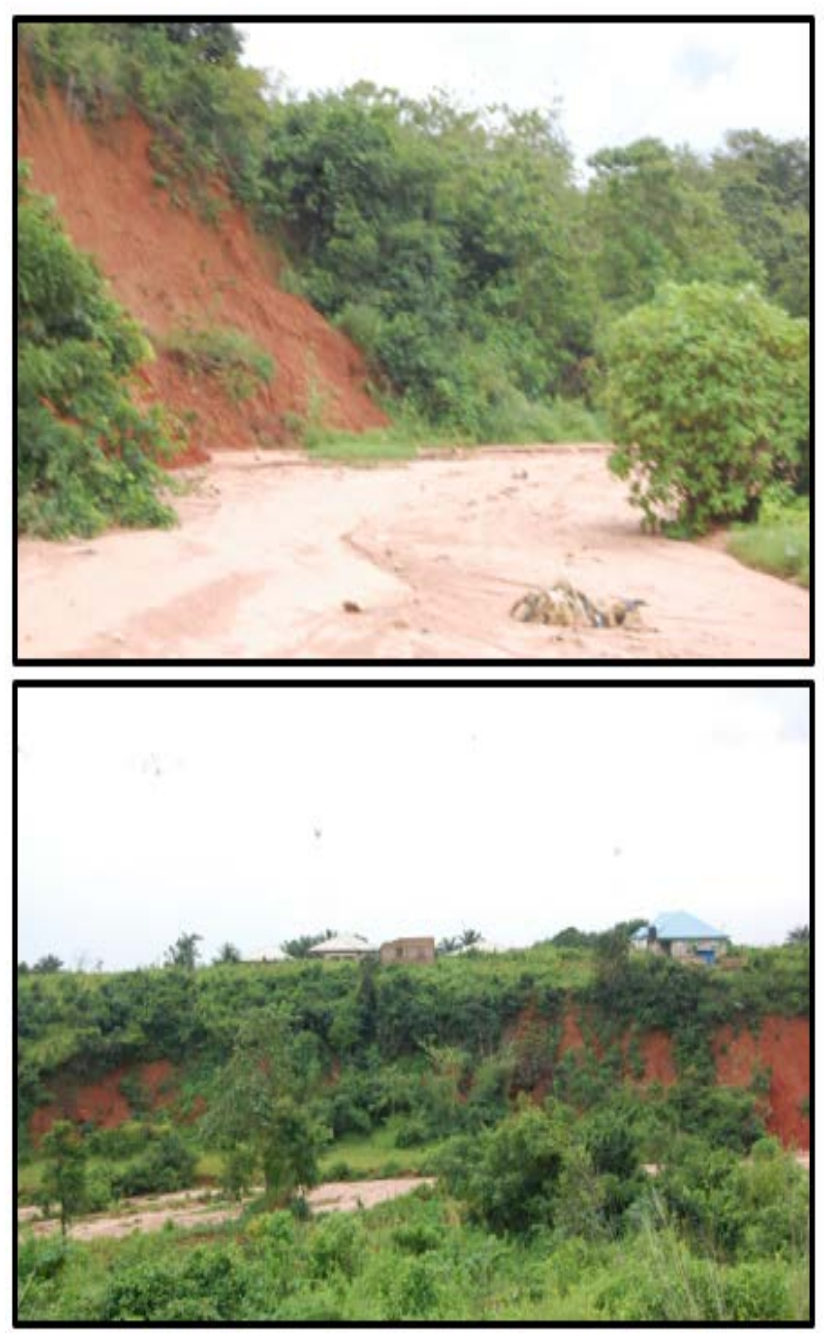

Figure 1. Some landslide locations in Ebem community, Ohafia

The conventional seismic refraction methods involve shooting seismic sources in the forward or reverse direction, or both, to determine near surface characteristics which include subsurface layer velocities and the depth to bedrock. These methods make use of intercept-time and travel path slope reciprocity to layer velocities and depths to bedrock only at the shot locations but not along the profile as we would have for the refraction tomography. Unless computed parameters are interpolated along profile lines or several shots are taken which are then individually processed and interpreted, information on the lateral variation in velocities and overburden thickness along the profile would not be obtained. Additionally, erroneous velocity estimation could be made at the shot locations and this could lead to errors in the overall estimated thickness of the overburden. Consequently, the conventional refraction methods have limitations in applicability in areas of complex velocity structures and steeply dipping and discontinuous refractors such as are associated with landslides, although they have been applied in the past in landslide studies in the determination of depths to failure surfaces and lateral extent of landslides [10,11,12,13,14]. Shots in the context of this study, constitute seismic waves which are generated by the seismic source, which cause motion of rock materials as they propagate through the materials. The propagating waves are elastic, as they do not cause permanent deformation of the earth materials; the materials return to their original, undisturbed position after passage of the waves. In principle, emphasis is placed on the first arrival times of the critically refracted seismic energy which have returned to the surface and are recorded at the recording stations. The methods are applicable in engineering in the determination of the depth to bedrock, and in environmental and groundwater exploration for mapping the water table $[3,15,16]$.

In the study, we employed seismic refraction tomography to determine the velocity structure and overburden thickness in Ebem, a community in Ohafia Local Government Area of Abia State, Nigeria, that had suffered numerous erosional landslides with the aim of providing information on active or likely slide zones, to mitigate the risks associated with the landslides frequently occurring in the community and reduce future disasters, in addition to offering geological explanation to the frequent occurrences. The tomography method utilized in this work does not require an assumption of initial velocity structure or layering, but uses only the first arrival travel time and the data acquisition geometry as input to determine the near surface characteristics of the area.

\section{Location and Geological Setting of the Area}

This study was conducted in Ebem community in Ohafia Local Government Area of Abia State, Nigeria (Figure 2). The Ohafia area is located within latitudes $5^{\circ} 30^{\prime} \mathrm{N}$ to $5^{\circ} 45^{\prime} \mathrm{N}$ and longitudes $7^{\circ} 45^{\prime} \mathrm{E}$ to $7^{\circ} 55^{\prime} \mathrm{E}$. It consists of eight autonomous communities, covering a land area of approximately $1,050 \mathrm{~km}^{2}$. Annual average temperature ranges and rainfall is $23^{\circ} \mathrm{C}$ to $32^{\circ} \mathrm{C}$, and 1,400 $\mathrm{mm}$, respectively [17]. The area is saddled with numerous hills and valleys, and only a few flat terrains occasioned by frequent erosions and landslides.

The area is located in the south eastern part of the Anambra Basin, a late Cretaceous - Palaeocene proto Niger - Benue delta complex located in the southern part of the regionally extensive northeast-southwest trending Benue Trough. The geology of the area comprises deltaic 
marine sediments of the Cretaceous age to recent, with three formations which include the Ajali, Bende-Ameki and Asata Nkporo Formations. Whereas the Ajali Formation which lies topmost contains red earth sandstones which are poorly sorted and very permeable, the Bende-Ameki which is intermediate, contains white sandstones which are medium-to-coarse grained, with streaks of silts, clays and limestones. The Asata-Nkporo Formation underlies the Bende-Ameki, and comprises mainly shale mudstones which are blueish to darkish grey. The late Maastrichtian Ajali Formation is the main water-bearing Formation in the area [18,19].

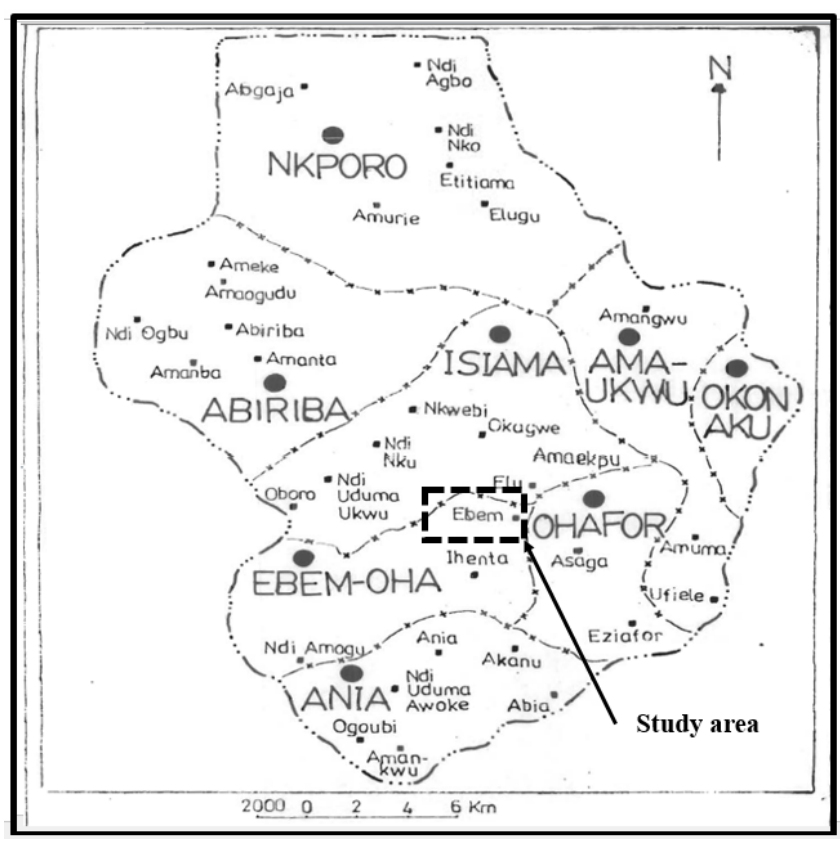

Figure 2. Map of Ohafia Local Government Area showing the study location

\section{Materials and Methods}

\subsection{Data Acquisition}

The field setup for data acquisition is shown in Figure 3. A 12-channel ABEM Terraloc MK III digital seismograph was used for data acquisition for this study. The geophones were spaced $10 \mathrm{~m}$ apart, and were firmly pinned vertically on the ground at properly marked-out stations along each profile. To ensure sufficient data are acquired for the tomography inversion, an offset distance of $23.5 \mathrm{~m}$ was used before the first geophone group and after the last geophone group, to give a total of $157 \mathrm{~m}$ for each profile. The shots constituted hitting a metal plate with a $6 \mathrm{~kg}$ sledge hammer five (5) times consecutively, and this was done at every geophone station, and at the $23.5 \mathrm{~m}$ offset before and after the first and last geophone stations, respectively. Seismic waves generated by the shots are picked up by the geophones and transmitted for recording by the seismograph, which automatically digitizes the incoming seismic signals and stores them for onward processing. Three (3) profile locations, each 157 $\mathrm{m}$ long, were occupied in the community.

\subsection{Data Processing, Results and Discussion}

Windows-based Reflex-2D software was used for the processing and interpretation. The processing entailed data reformatting to the software format, after which a Butterworth bandpass filter was applied, setting the upper and lower frequency cut-offs to $100 \mathrm{~Hz}$ and $5 \mathrm{~Hz}$, respectively. It was assumed that no useful frequency above the upper threshold would be present in the data, and the lower frequency cut-off was aimed at removing ground roll and other lower frequency signals for overall improvement of signal-to-noise ratio in the data. Due to the effect of geometric spreading, absorption and scattering, amplitudes of seismic signals become weaker with propagation distance from the shot. To compensate for amplitude loss arising from these factors, an exponential gain correction was applied to the data to improve their quality and facilitate accurate picking of the first refraction travel time arrivals which are used for the tomographic inversion. Figure 4 shows refraction monitor record for one of the shots post application of the gain.

The first break picking module in the software was used for picking the first arrival times on the processed data. The three profiles were analyzed using the conventional intercept and reciprocal methods for forward and reversed shots, and also tomographic inversion method. Figure 5 Figure 7 show plots of first arrival times versus geophone stations for the first forward and reversed shots. Qualitative interpretation of the conventional travel time versus geophone station plots shows one distinct refractor (two layers) whose average first arrival time at the recording stations for the three profiles is $29.67 \mathrm{msec}$.

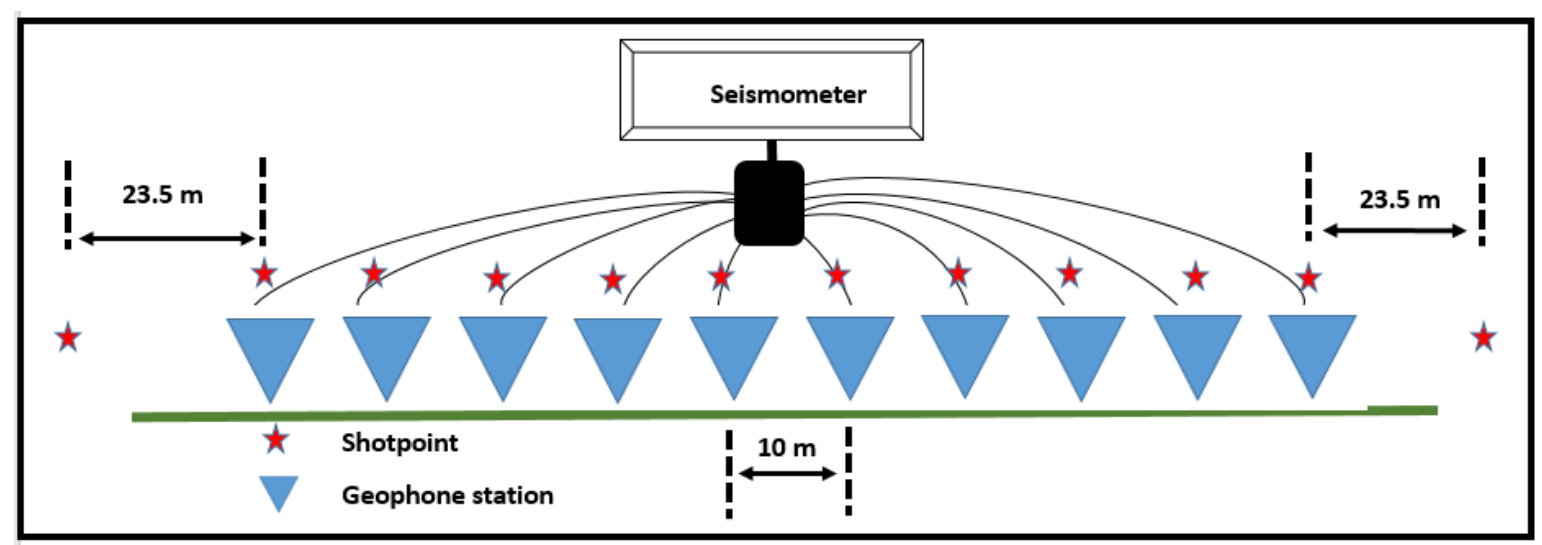

Figure 3. Field setup for tomographic data acquisition 
4 Reflenv-20-ditannalysis

File Golal Plot View Processing Analyis Help Ext

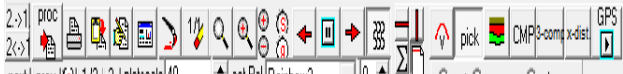

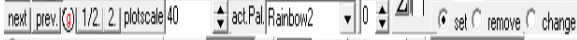

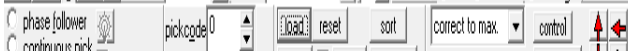

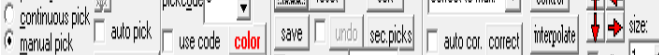

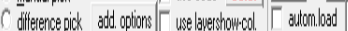

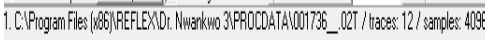

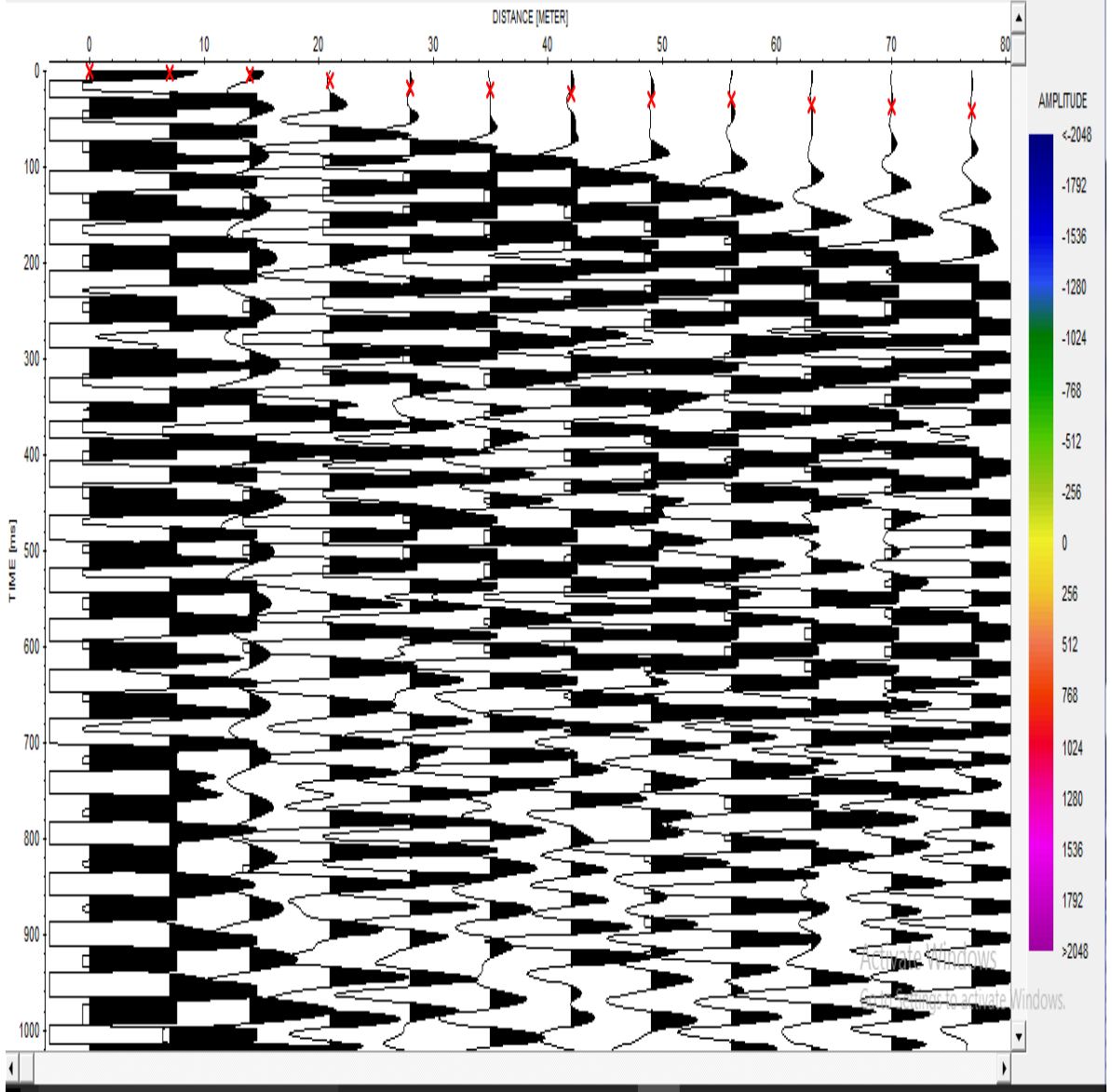

Figure 4. Shot record after gain application

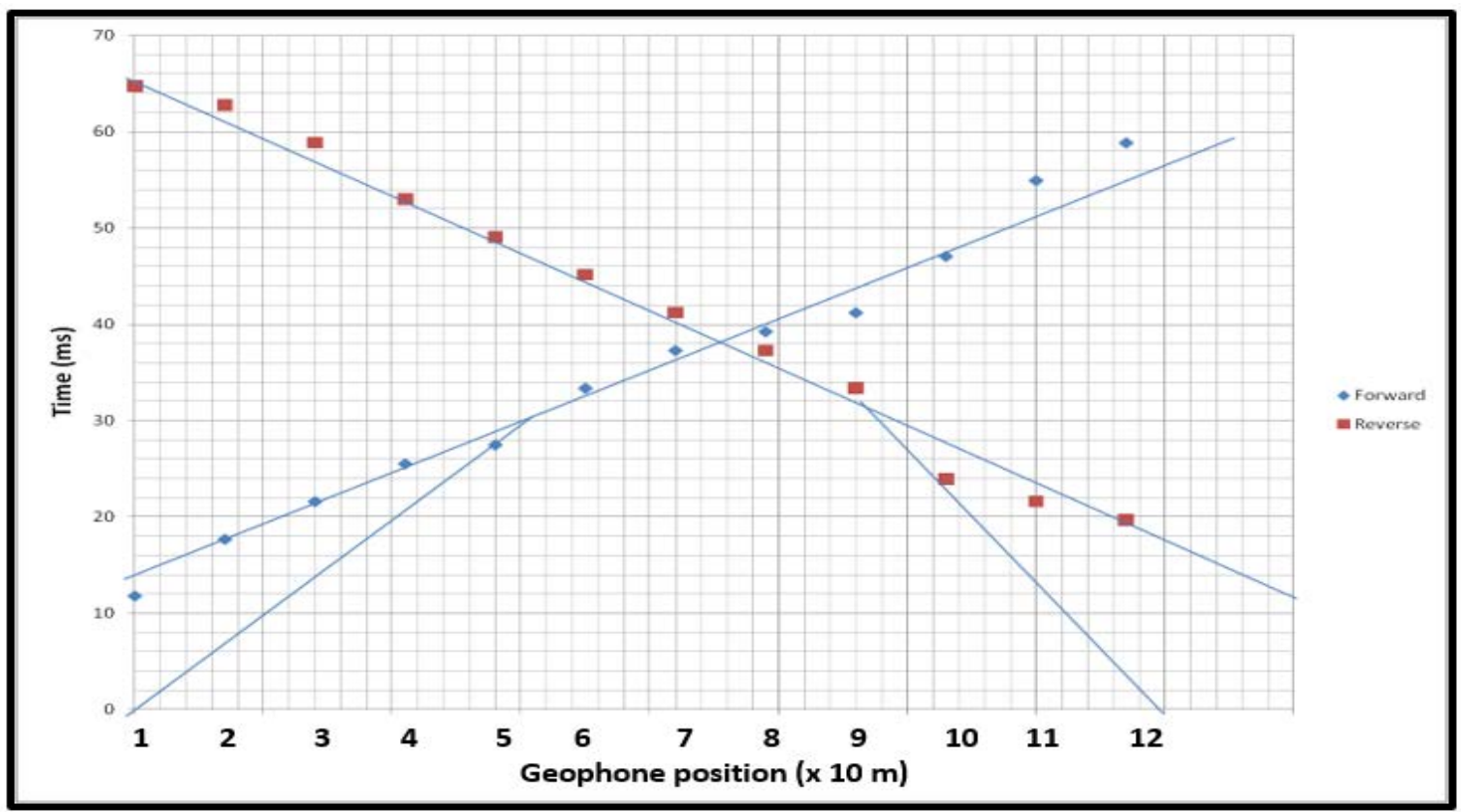

Figure 5. Time-distance plot for the first forward and reversed shots for profile 1 


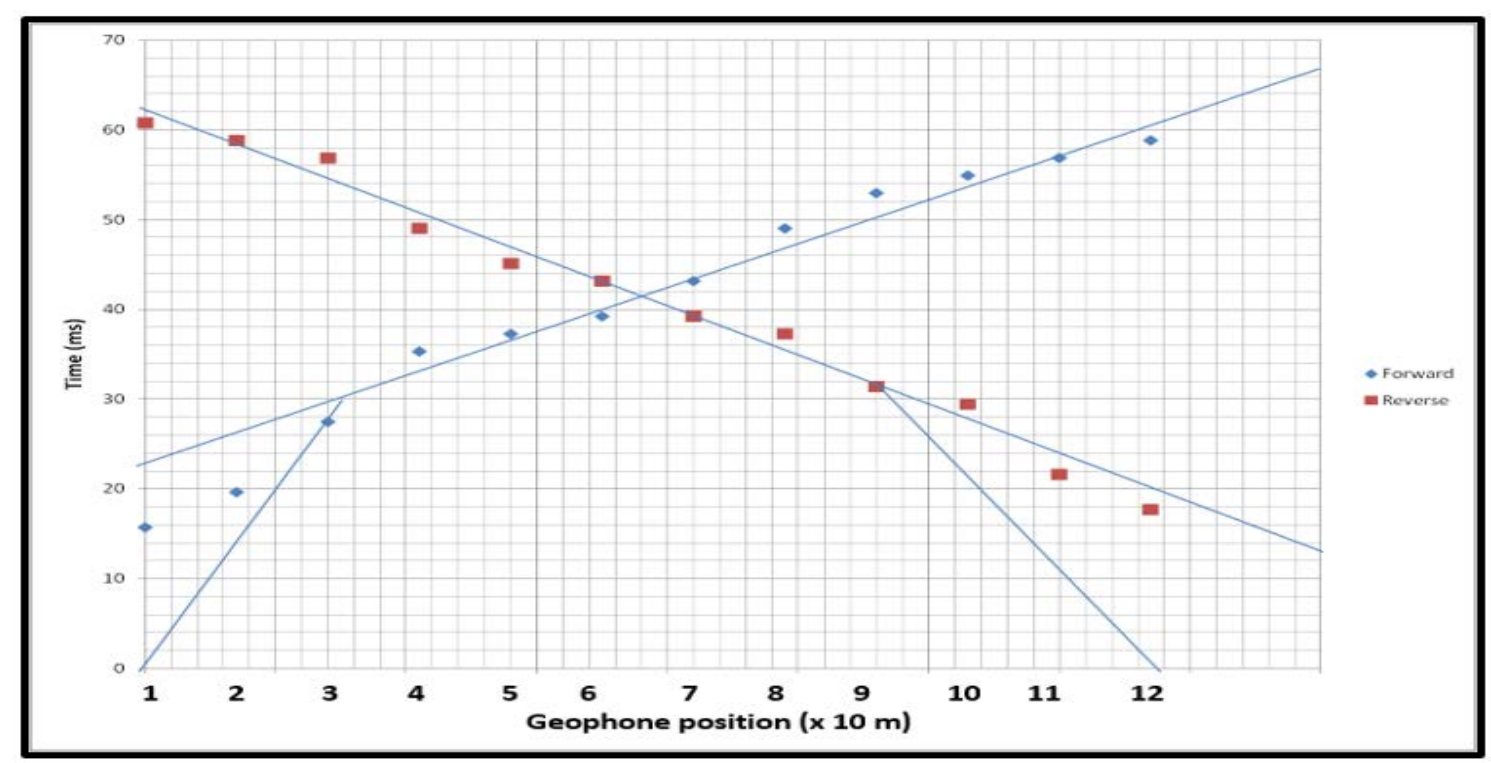

Figure 6. Time-distance plot for the first forward and reversed shots for profile 2

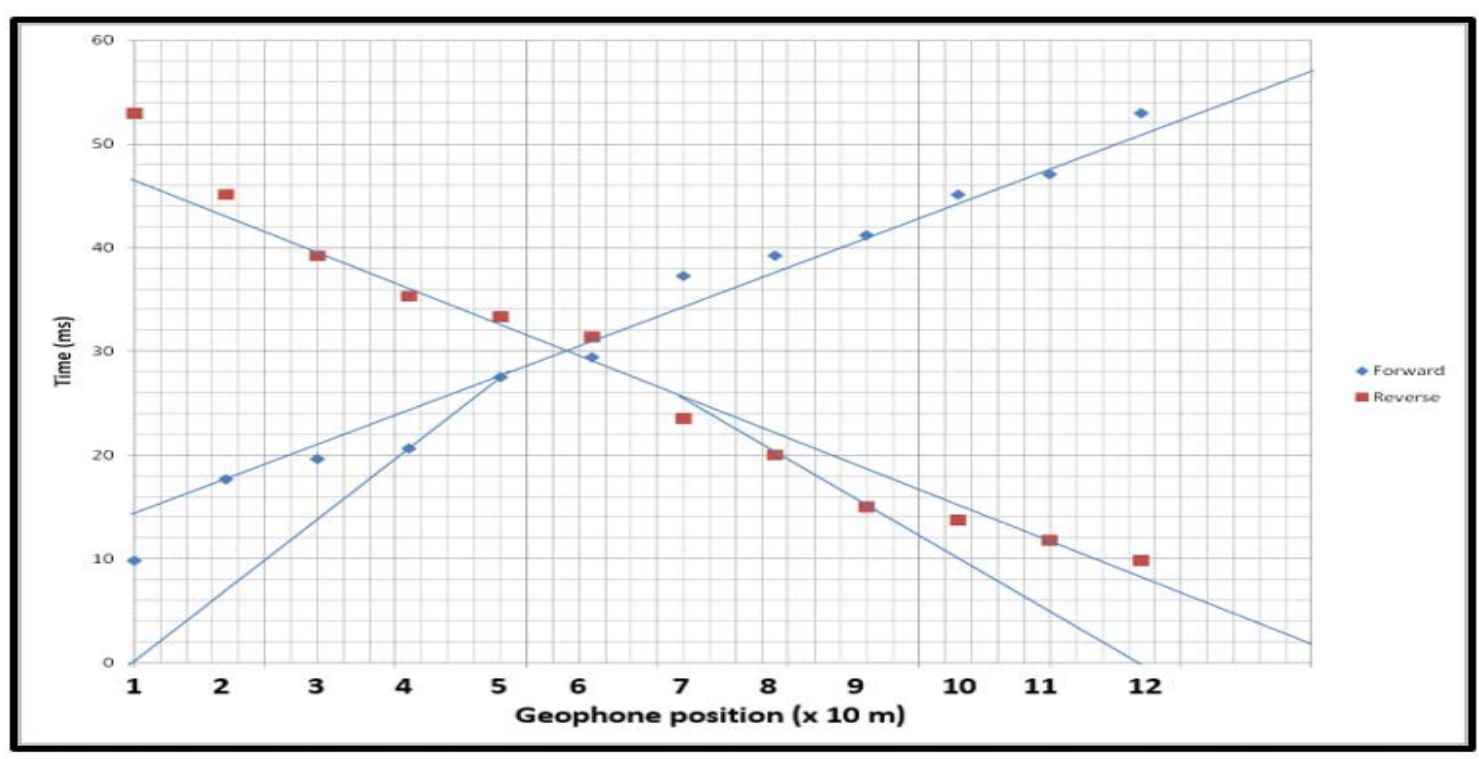

Figure 7. Time-distance plot for the first forward and reversed shots for profile 3

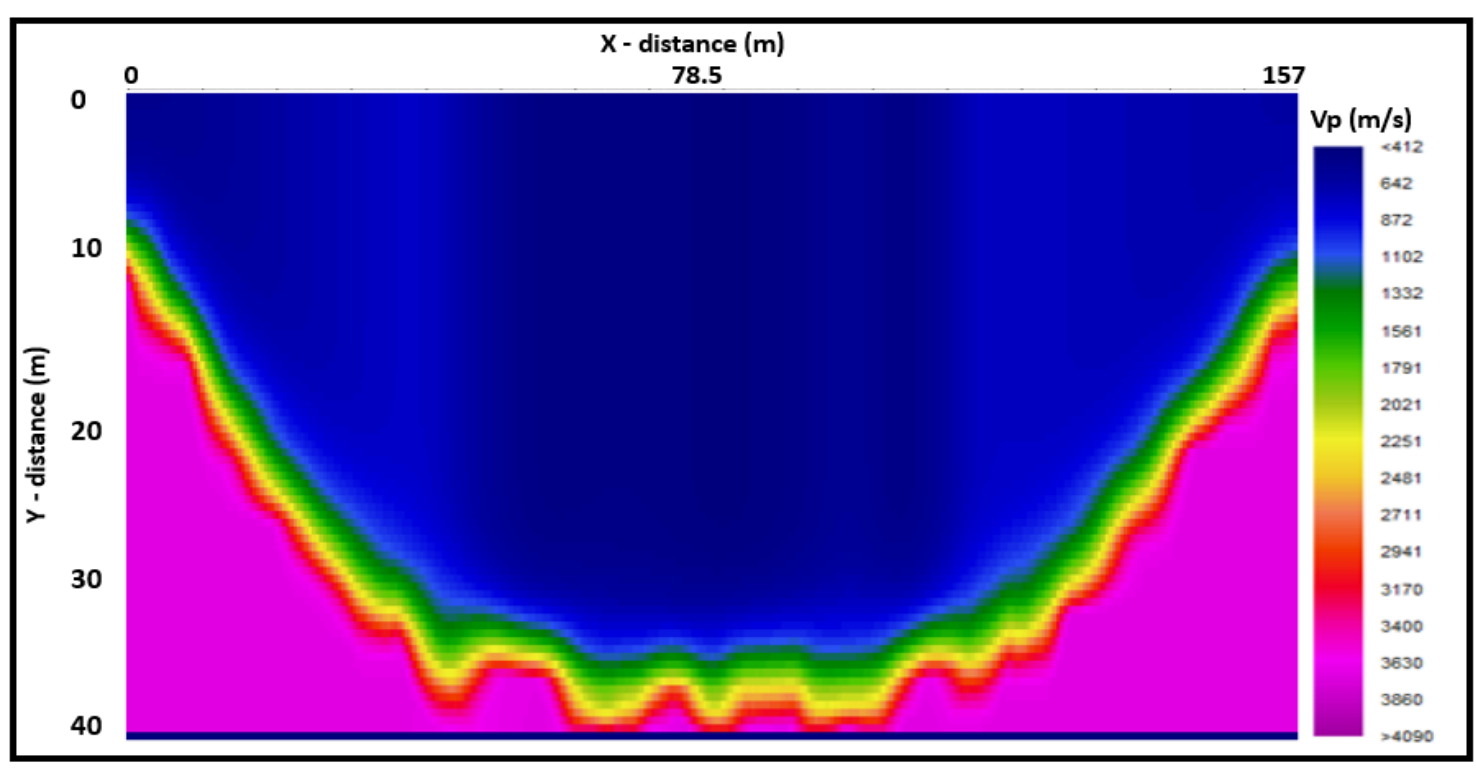

Figure 8. Typical velocity distribution model in Ebem 
The velocity model obtained for each of the three profiles showed good correlation from one profile to the other; the models did not vary much between the profiles. This is in agreement with results of the qualitative interpretation of the travel time curves, except that the tomography result shows three layers in terms of velocity distribution instead of the two layers that are visible on the travel time curves. Figure 8 is the typical velocity model obtained for the area showing the near surface velocity structure of the area. The tomogram shows distinctly three different layers of compressional velocity distribution which include a top layer, an intermediate layer and the bedrock. This reflects the vertical and lateral variations in lithology of subsurface materials in the area.

The top layer has velocity ranging from about $412 \mathrm{~m} / \mathrm{s}$ to about $1,300 \mathrm{~m} / \mathrm{s}$. This layer is interpreted to be the weathering layer on account of its low velocity [20] and contains unconsolidated red earth sands. Its average thickness ranges from about $9 \mathrm{~m}$ at the flanks to $35 \mathrm{~m}$ at the center. The top layer is underlain by a thin, relatively uniform sub-weathered layer of intermediate compressional velocity ranging from about $1,300 \mathrm{~m} / \mathrm{s}$ to about 3,000 m/s and thickness ranging from about $2.31 \mathrm{~m}$ to $3.01 \mathrm{~m}$. This layer is apparently more compacted than the overlying weathering layer, and is thought to comprise sands and a mixture of clay, on account of the regional geological setting of the area. Compressional velocities in the bedrock are generally higher than $3,000 \mathrm{~m} / \mathrm{s}$. The compressional velocity in the area generally increases with depth from about $412 \mathrm{~m} / \mathrm{s}$ to $4,090 \mathrm{~m} / \mathrm{s}$. Thickness of the overburden in the area varies from about $12 \mathrm{~m}$ at the flanks to $35 \mathrm{~m}$ at the center, creating a thick zone of low compressional velocity layer at the center. This feature in the velocity distribution may not be unconnected with the unconsolidated nature of the sands which constitute the top soil following long periods of erosion in the area. The frequent landslides in the area can be attributed to the thick, largely unconsolidated overburden sitting below the earth surface almost across the entire community. This region is presumed to act as a sinkhole for surface water run-offs which is being added to the soil by rainfall and other human activities. They are also the most vulnerable to sliding and must be avoided for engineering construction purposes unless adequate measures are put in place to ensure competence of the engineering constructions. Also, proper drainage systems designed to drain surface water away from the thick overburden regions would be another way to mitigate the frequent landslides in the area.

\section{Conclusion}

We carried out seismic refraction tomography in Ebem community to offer possible geologic explanation to the frequent landslides occurring in the community and suggest measures to mitigate future occurrences. Velocity structure obtained from the study has shown that the area is made up of three different layers on the basis of velocity distribution; the velocity generally increasing with depth from the surface. The weathering layer, which contains unconsolidated sands is very thick at the center, reaching about $35 \mathrm{~m}$ but much thinner at the flanks. The intermediate layer, assumed to be the sub-weathering layer is generally very thin, not exceeding $3.2 \mathrm{~m}$ in the area. Seismic velocity in the area ranges from about $412 \mathrm{~m} / \mathrm{s}$ to about $4,090 \mathrm{~m} / \mathrm{s}$. with the bedrock generally having velocities exceeding $3,000 \mathrm{~m} / \mathrm{s}$. The frequent landslides in the area is likely caused by the thick, unconsolidated and permeable overburden which presumably acts as a sinkhole for surface water run-offs orchestrated by frequent rainfall in the area. Areas where the weathering layer is thick are likely the most vulnerable to slides and must be avoided for engineering construction purposes in order to mitigate future disasters in the area.

\section{References}

[1] Jegede, S.I., Osemeikhian, J.E.A., Osazuwa, I.B., Ujuanbi, O. and Emekeme, R.E., 2008, Near surface investigation of groundwater contamination in the Ragolith Aquifer of the Zaria basement complex and seismic refraction tomography, Book of Abstracts for $31^{\text {st }}$ NIP Ann. Conference.

[2] Osazuwa, I.B., Chiemeke, C.C., Olatunji, S. and Osumeje, J.O., 2008, Use of seismic refraction tomography to delineate subsurface trough for the evaluation of the water potential in parts of Zaria, Book of Abstracts, $31^{\text {st }}$ NIP Ann. Conference.

[3] Chiemeke, C.C. and Aboh, H.O., 2012, Delineation of aquiferous Layers within the basement complex using joint inversion of seismic refraction tomography and 3D seismic reflection survey, Archives of Applied Science Research., 4(1), p. 400-405.

[4] Tien-When, L.O. and Phillips, L., Fundamentals of seismic tomography, Geophysical Monograph Series, No. 6, SEG, Tulsa, 2002.

[5] Stewart, R. R., Exploration seismic tomography: fundamentals, Society of Exploration Geophysicists, Tulsa, OK, 1991.

[6] Kearey, P., Brooks, M., \& Hill, I., An introduction to geophysical exploration ( $3^{\text {rd }}$ ed.). Blackwell Science Ltd., 2002.

[7] Zhu, X. and Mc Mechan, G.A., 1989, Estimation of two-dimensional seismic compressional wave velocity distribution by interactive tomographic imaging, Internat, J. Image Systems Technology, 1, p. 13-17.

[8] Stefan, J.P., 1995, Tuning-ray tomography, Geophysics, 60, p. 1917-1929.

[9] Azwin, I.N, Saad, R. and Nordiana, M., 2013, Applying the seismic refraction tomography for site characterization, APCBEE Procedia, 5, 227-231.

[10] Cummings, D., and B. R. Clark, 1988, Use of seismic refraction and electrical resistivity surveys in landslide investigations, Bulletin of the Association of Engineering Geologists, 15(4), p. 459-464.

[11] Bogoslovsky, V. A., and A. A. Ogilvy, 1977, Geophysical methods for the investigation of landslides, Geophysics, v. 42, n. 3 p. 562-571.

[12] Brooke, J. P., 1972, Geophysical investigation of a landslide near San Jose, California, Geoexploration, 11(2), p. 61-73.

[13] Carroll, R. D., J. H. Scott, and F. T. Lee, Seismic refraction studies, in Geological, geophysical and engineering investigations of the Loveland Basin landslide, Clear Creek county, Colorado, 1963-65, U.S. Geological Survey Professional Paper 673 C, p. 17-19, 1972.

[14] Trantina, J. A., 1963, Investigation of landslides by seismic and electrical methods, Special Technical Publication 322, American Society for Testing and Materials, Philadelphia, PA, p. 120-133.

[15] Ugwu, S.A., 2008. Determination of depth to bedrock in Afikpo syncline of the Benue Trough, Nigeria, using seismic refraction methods.

[16] Ayolabi, E.A., L. Adeoti, N.A. Oshinlaja, I.O. Adeosun and O.I. Idowu, 2009. Seismic refraction and resistivity studies of part of Igbogbo township, south-west Nigeria. J. Scient. Res. Dev., 11: 42-61.

[17] Eke, K.T. and Igbokwe, M.U., 2011, Geoelectric investigation of groundwater in Ohafia locality, Abia State, Nigeria, British Journal of Applied Science and Technology, 1(4), p. 190-203. 
[18] Hoque, H. M., Ezepue, M. C. (1977). Petrology \& Palaeogeography of the Ajali sandstone, Nigeria. Journal of Mining \& Geology, 14, 16-22.

[19] Ibe, K. K. et al. (1998). Natural fluoride levels in some springs and streams from the Late Maastrichtian Ajali Formation in
Ohafia-Arochukwu area of South Eastern Nigeria. OdontoStromatologie Tropicale, 87, 1998.

[20] Parasnis, D.S Principles of applied geophysics, Chapman and Hall, London, 1986.

(C) The Author(s) 2019. This article is an open access article distributed under the terms and conditions of the Creative Commons Attribution (CC BY) license (http://creativecommons.org/licenses/by/4.0/). 